\title{
Living Off Wetlands: A Case Study of Mara Bay and Masirori Wetlands, Tanzania
}

\author{
David Omolo', Philip Kibet Langat'², Richard Koech ${ }^{3}$, Yong Jiang4 \\ ${ }^{1}$ International Water Association, The Hague, The Netherlands \\ ${ }^{2}$ School of Environmental and Rural Science, University New England, Armidale, Australia \\ ${ }^{3}$ School of Health, Medical and Applied Sciences, Central Queensland University, Bundaberg Campus, Bundaberg, Australia \\ ${ }^{4} \mathrm{IHE}$ Delft Institute for Water Education, Delft, The Netherlands \\ Email: *plangat@myune.edu.au
}

How to cite this paper: Omolo, D., Langat, P. K., Koech, R., \& Jiang, Y. (2018). Living Off Wetlands: A Case Study of Mara Bay and Masirori Wetlands, Tanzania. Journal of Geoscience and Environment Protection, 6, 43-60.

https://doi.org/10.4236/gep.2018.612003

Received: October 22, 2018

Accepted: December 3, 2018

Published: December 6, 2018

Copyright $\odot 2018$ by authors and Scientific Research Publishing Inc. This work is licensed under the Creative Commons Attribution International License (CC BY 4.0). http://creativecommons.org/licenses/by/4.0/

\section{Open Access}

\begin{abstract}
This study was undertaken to help highlight the negative impacts of economic activities on wetlands in East Africa with a specific focus on Mara Bay and Masirori wetlands, Tanzania, a region where the local communities still harness wetland resources for economic sustenance. Key economic activities and the negative impacts of the income-generating activities on the wetlands are identified, including the main goods harnessed, level of dependency of the locals to the wetlands, and the level of environmental knowledge of the locals on the wetlands' ecosystem services. Both qualitative and quantitative tools and techniques viz.: questionnaires, semi-structured interviews, market surveys and spreadsheet analysis were used in this study. The proportion of wetland users involved in papyrus harvesting, food crop cultivation and fishing was $30 \%, 25 \%$ and $24 \%$, respectively while charcoal/firewood and grass for livestock accounted for $12 \%$ and $7 \%$, respectively. Significant differences in incomes for charcoal $(p<0.05)$ across the four villages were recorded but farming, fishing, mat making, herding and fish mongering were non-significant. About $6 \%$ of those interviewed had some considerable knowledge on wetland ecosystem services, while the rest (94\%) lacked information. Issues identified as having detrimental impacts on the wetlands' ecosystem services included conversion of sections of the wetlands into farmlands, grazing, charcoal burning, unsustainable fishing, overharvesting of papyrus and brick-making. Farming was found to be a major income-generating activity within the two wetlands. Other important economic activities were charcoal burning, fishing, mat making and fish mongering. The findings from the research are useful for devising appropriate strategies for wetland conservation. Such measures may include assigning wetland ecologists to the village governments, valuation of the wetlands, commissioning of a price and resource regulatory
\end{abstract}


board for the wetland goods, creation of wetlands monitoring program, a fining regime system and a roll-out of mass environmental education in the wetlands regions.

\section{Keywords}

Wetlands, Wetlands Goods, Wetlands Ecosystem Services, Wetland Marks, Economic Sustenance, Livelihoods

\section{Introduction}

Wetlands are natural or artificial ecosystems where water is the main component controlling the environment and its flora and fauna (Ramsar Convention Secretariat, 2013). Water found in wetlands may be static or flowing, and its quality may range from fresh to salty. Wetlands are prevalent in areas where the water table is near the surface and where the habitat is submerged in shallow waters. These include coastal areas, estuaries, and areas around lakes and along rivers and streams. Wetlands provide provisioning, hydrological, geochemical and cultural benefits, which are commonly referred to as ecosystem services (Peh et al., 2013; Costanza et al., 1997; Davidson, 2014). They provide a variety of products and services which include: food such as fish and other aquatic animals; fresh water; and fibre and wood fuel. They also provide buffer zones and regulate floods and flow regime in landscapes, thereby preventing flooding incidences (Kadykalo \& Findlay, 2016). They act as carbon sinks, and thus help combat climate change (Patton et al., 2015) as well as acting as valuable filters and pathogen removers in drinking water, which helps in maintaining good health (Wu et al., 2016). These areas are biodiversity hotspots, with different species of flora and fauna. Wetlands are generally attractive areas, and are often used for recreational, educational and spiritual activities. In Africa, wetlands make up about $16 \%$ of the total land (Koohafkan et al., 1998) and virtually support the livelihood of the local communities living around them (Taylor et al., 1995).

In spite of the immense benefits of wetlands, in the pre-1960s, there was little focus on their conservation, partly because of low levels of environmental degradation at the time. Globally, the start of the 1960s marked a period of awareness about the need for wetland conservation which eventually culminated into the Ramsar Convention on Wetlands and its adoption in 1975 (Ramsar Convention Secretariat, 2013). The adoption of Ramsar Convention saw the listing of several wetlands as protected areas for conservation purposes.

However, wetlands have continued to face threats due to increased human activities which have led to increased degradation and total disappearance in some instances globally (Durigon et al., 2012; Turner, 1991; Hettiarachchi et al., 2015; Barbier, 1993). Demographic growth, increasing poverty, unsustainable farming and rising economic stresses are the major contributors to wetland losses in 
Africa. These stressors are further exacerbated by increased drought spells (Schuijt, 2002). The East-African region where the great Lake Victoria Basin lies has a number of wetlands that have been degraded in the recent years (Majamba. 2004; Mombo et al., 2013). These wetlands are surrounded by people who are living below the poverty line (Van Dam et al., 2014).

Wetlands in Tanzania make up about $10 \%$ of the total land mass, and out of this, about 5.5\% are categorized as Ramsar sites (Guidelines for Sustainable Management of Wetlands, 2014). The Masirori and Mara Bay wetlands are located in the Mara province, Tanzania, and form part of the Great Lakes region. This region has been marked as a very important area for terrestrial and freshwater biodiversity conservation (Crisman, 2001). In the recent times, however, these wetlands have come under focus due to anthropogenic pressures (Sakane et al., 2011; Beuel et al., 2016; Hoffman et al., 2011). There is urgent need to assess negative impacts of economic activities with these wetlands to inform management strategies and policy decision-making. There is currently no study, at least by the time this study was undertaken, on the negative impacts of economic activities on wetlands in East Africa, and in particular, the Mara Bay and Masirori wetlands.

This research was aimed at making a contribution towards sustainable utilisation and management of wetlands, using Mara Bay and Masirori Wetlands as case studies. In order to do this, it was important to engage and understand pertinent issues faced by the people living off these wetlands. The specific objectives of the research were to: 1) identify the key economic activities undertaken 2) investigate the main goods harnessed; 3) assess the level of dependency of the locals to the wetlands; 4) identify the negative impacts of the income generating activities on wetlands; 5) and, assess the level of environmental knowledge of the locals. The findings from the research would then be used to devise appropriate strategies for wetland conservation.

\section{Materials and Methods}

\subsection{Study Area}

Masirori and Mara Bay wetlands are part of the greater Mara River Basin which is one of the transboundary basins in East Africa. Mara Basin extends over an area of roughly $13,750 \mathrm{~km}^{2}$ from Masai Mara National Reserve on the Kenyan side into Tanzania through the Serengeti National Park before ending along the shores of Lake Victoria. The Mara River originates from the Mau escarpment in Kenya, flows through Masai-Mara and Serengeti National Parks and drains its water to Lake Victoria in Tanzania. Approximately two thirds of Mara Basin is in Kenya, and the rest is in Tanzania.

The Mara Bay and Masirori Wetlands lie on the southern part of the Mara River Basin (Figure 1) and cover an area of about $500 \mathrm{~km}^{2}$. The annual rainfall in the lower reaches of the Mara Basin where the two wetlands are located range from 500 to $800 \mathrm{~mm}$. The two wetlands currently have no formal protection 


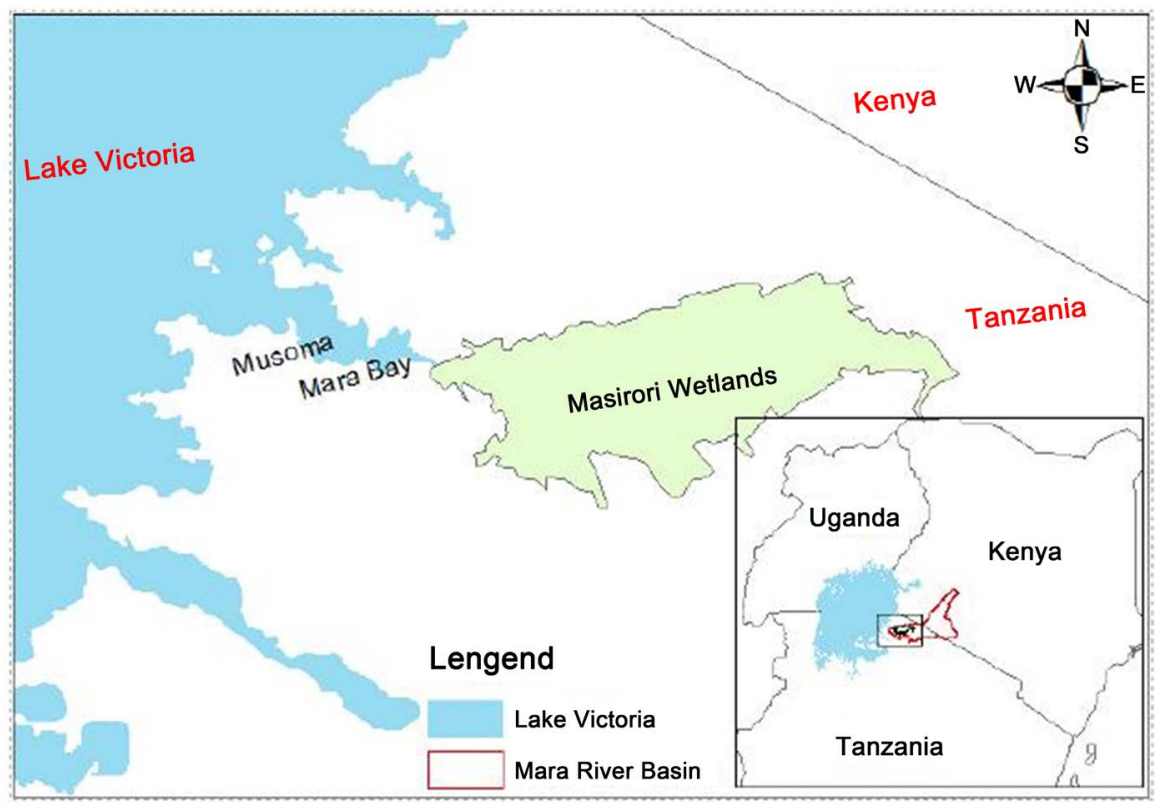

Figure 1. Location map showing the Mara Bay and Masirori Wetlands.

status, although they are only listed as "Important Bird and Biodiversity Areas." They are protected by the Tanzanian law under the Environmental Management Act of 2004, Wildlife Conservation Act of 2009, and Water Resources Management Act of 2009. The wetlands are known to have more than 20 plant species, 226 bird species, 14 fish species, and 30 species of terrestrial and semi-aquatic mammals.

This portion of the Mara River Basin in Tanzania administratively falls under Mara Province. The land in the area is government-owned and controlled. The economy of the area is marked with high rural poverty, hinged on small-scale farming and fishing, with a majority of its populace relying on wetland products for economic sustenance and wellbeing. The Mara Bay and the Masirori Wetlands are surrounded by 16 villages of which 8 of them lie on the northern side, namely: Bisarwi, Kwibuse, Nyamerambaro, Nkerege, Kembwi Marasibora, Nyanchabakenye and Surubu; and the remaining 8 namely: Kongoto, Buswahili, Kirumi, Wegero, Ryamisanga, Kwisaro, Kitasakwa and Bukabwa lie on the southern side.

In this study, Buswahili, Marasibora, Kongoto and Kirumi villages were selected because of their close proximity to Lake Victoria and Mara River, and the relatively higher volumes of economic activities undertaken. On the other hand, Kongoto, Kitaramanka, Kiagata, Otegi, Musoma town, Kobwasa, Kirumi, Tarime and Ochuna markets were selected because of their close proximity to the four villages, and because they trade on the wetlands' goods. The study focused on key stakeholders who had immediate contact with the two wetlands such as: farmers, fishermen, mat-makers, fishmongers, herdsmen (those who harness wetland grass to feed their cows) and charcoal burners. Past studies (e.g. Dixon \& Wood, 2003; Scoones, 1991) have singled out these occupations as being in- 
tensively engaged in African wetlands.

\subsection{Data Collection and Analysis}

T In order to propose management strategies for the sustainable use of the Mara Bay and Masirori Wetlands, it was imperative to identify and engage with key wetland users who work on the wetlands on a day-to-day basis for their livelihoods. In order to understand the management and conservation issues in the two wetlands, various data sources were used and many respondents including the leaders of the water users' association and conservation officers were interviewed, alongside the use of focus groups, observations and market survey tools and techniques. The qualitative interview approach is a recognised method in nature conservation studies (Devetak et al., 2010), whereas market survey was an appropriate quantitative tool that generated answers that could be coded and analysed with parametric statistical methods to allow generalized conclusions to the whole population under study to be made. The tools and techniques used in this study are explained further in the following subsections.

Questionnaires

The questionnaires were administered face to face and the responses later transcribed into text by the interviewer. They were used to elicit both quantitative and qualitative information on how the respondents used the provisioning services to meet their livelihoods, and their perception and knowledge on wetlands.

The questionnaires contained both closed and open-ended questions. Closed-ended questions were mainly used to obtain data such as the wetland goods they harnessed, the markets the respondents opted to sell their wetland resource-based goods, the distance travelled, and how they delivered the goods to markets, and the time the respondents spent in harnessing these products from the wetlands and frequency. The amount of income the respondents obtained from selling the wetland goods and other alternative goods (if any) were also sought. This was important in order to understand the economic importance of these wetlands to the locals and to determine if they had other activities they relied on and what they had to forego. The frequency showed how reliant they are on the services provided by the wetlands.

Open-ended questions were used to gauge the respondents' understanding of meaning of wetlands, the importance of wetlands to them and their families, and the role played by wetlands to ensure the long-term well-being of communities living around them. In total, 116 people were interviewed during the study consisting of: 98 key wetland users, 14 water users' association leaders and 4 conservation officials. To ensure good representation and quality of information, a stratified random sampling process that exhibit socio-demographic characteristics of the wetland region was used and the respondents were encouraged to seek clarification and/or additional information whenever it was necessary. Table 1 shows the key wetland users and the timing of their interviews: 
Table 1. Key wetland users and timing of interview.

\begin{tabular}{|c|c|c|}
\hline Category of respondents & $\begin{array}{l}\text { Wetland products } \\
\text { harnessed and their uses }\end{array}$ & Timing and venue of interview \\
\hline Fishermen & $\begin{array}{l}\text { Harvest fish for food and } \\
\text { sale in the market. }\end{array}$ & $\begin{array}{l}\text { In the various markets whenever they took } \\
\text { their fish for sale. }\end{array}$ \\
\hline Farmers & $\begin{array}{l}\text { Grow crops for food and } \\
\text { sell the excess. }\end{array}$ & During field visits and wetlands surveys. \\
\hline Fishmongers & Supply of fish. & $\begin{array}{l}\text { During market visits and also when they } \\
\text { went to buy the fish from the fishermen in } \\
\text { the wetlands. }\end{array}$ \\
\hline Herdsmen & $\begin{array}{l}\text { Obtain pasture for their } \\
\text { cattle. }\end{array}$ & $\begin{array}{l}\text { In the field as they sought pasture for their } \\
\text { livestock. }\end{array}$ \\
\hline $\begin{array}{l}\text { Charcoal } \\
\text { burners/firewood } \\
\text { collectors }\end{array}$ & $\begin{array}{l}\text { Use plant biomass as fuel } \\
\text { for cooking and heating. }\end{array}$ & During market surveys. \\
\hline Mat-makers & $\begin{array}{l}\text { Use papyrus to make mats, } \\
\text { fishing traps and baskets. }\end{array}$ & $\begin{array}{l}\text { Within the wetlands during papyrus } \\
\text { harvesting, in the markets, and during } \\
\text { wetlands surveys. }\end{array}$ \\
\hline
\end{tabular}

Semi-structured interviews

Semi-structured interviews in this study leveraged on the information already collected using questionnaires to obtain further information on some important aspects, particularly how the respondents understood environmental services provided by the two wetlands, and the challenges hindering the wetland conservation efforts. The leaders of the water user's association, from both the northern and southern side of the catchment, were interviewed during a capacity building workshop. Officials working for a local conservation group, Birdlife International Tanzania, conservation officials were also interviewed.

A total of 14 water users association leaders, from both the northern side and southern side of the Mara were interviewed using semi structured interviews. The issues covered during the interviews included the utilisation of the two wetlands by the key wetland users and levels of environmental knowledge amongst the wetland users. Four conservation officials who work with the locals in the two wetlands were also interviewed, and the issues covered included challenges encountered in conservation of the two wetlands, and possible measures for mitigation.

\section{Market surveys}

Markets around the study areas where the goods from the wetlands were sold were surveyed and market representatives interviewed. The questionnaires administered to the traders and sellers in the market surveys were different from the ones administered to the key wetland users in that they focused only on the wetland goods brought to the market and their prices. A total of twenty traders from the eight markets covered were interviewed.

\subsection{Data Analysis}

The quantitative data on income was analysed using Excel ${ }^{\circledR}$. The total income 
from each of the villages, incomes from each occupation, and percentages of key wetland users, from the actual number of people were calculated. One-way ANOVA was further used to check if there were statistically significant differences across the villages in terms of income and income per occupation per person, and across the villages and occupations in terms of time. The objective of this analysis was to test homogeneity of the treatments. This analysis technique was preferred because it is a relatively robust procedure with respect to violations of the normality assumption (Kirk, 1995). Using Excel $^{\circledR}$ spreadsheet, the total number of commodities mentioned by the respondents was calculated. Grouping of the commodities and percentage distribution were calculated and visualised in $\operatorname{Excel}^{\circledR}$. The time spent in the wetlands was analysed using Excel $^{\circledR}$ to get the percentages across the villages.

\section{Results and Discussion}

In total 98 wetland users drawn from the four villages: Buswahili (29), Kongoto (37), Kirumi (11) and Marasibora (21) were interviewed for this study. Out of these, $45 \%$ were males and $55 \%$ were females. The various occupations of these respondents are shown in Table 1. The level of education of the respondents was varied, with the majority (77\%) having only primary school level education, while $4 \%$ and $17 \%$ had secondary school level education and no education, respectively. The ages of the respondents varied, with the oldest being 70 years and the youngest 19 years old. The greatest number of people interviewed were in the age group 30 - 39 years.

The statistics from the survey in the two wetlands reflected the national trends, and closely matched with the 2012 Tanzanian National Census which indicated that the total population had $48.7 \%$ males and $51.3 \%$ females, and showed that $81.7 \%$ and $14.4 \%$ had primary and secondary-level education respectively (The United Republic of Tanzania, 2012).

\subsection{Commodities Harnessed from the Wetlands}

The goods harnessed from the wetlands which support the major economic activities in the study area are shown in Table 1. The proportion of wetland users who were found to be involved in papyrus harvesting, food crop cultivation and fishing was $30 \%, 25 \%$ and $24 \%$, respectively (Figure 2). The main food crops grown in the study area included maize, sorghum, millet, rice and watermelon. Charcoal/firewood and grass for livestock accounted for 12 and 7\%, respectively (Figure 2).

Similar findings were obtained by Ajwang et al. (2016) in a similar catchment in the Lake Victoria Basin (Ombeyi wetland in Kenya), where papyrus was found to be the major commodity harnessed by the wetland users interviewed at 93.4\%, followed by farming (76.1\%), fishing (41.8\%) and firewood (8.5\%).

\subsection{Income Generated from the Wetlands across the Four Villages}

The income generated from the four villages in the survey (Table 2), demonstrated 


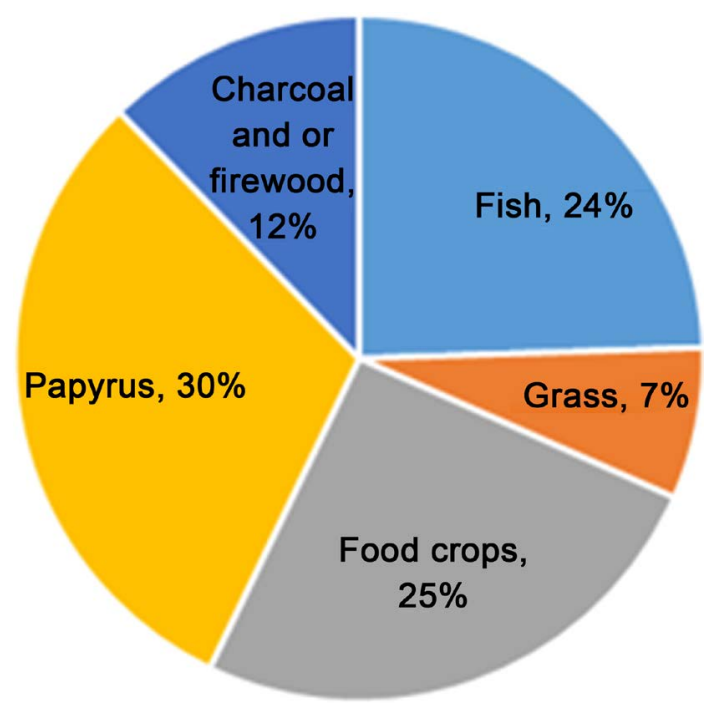

Figure 2. Percentage of key wetland users harnessing wetland commodities.

Table 2. Weekly income generated from the four villages.

\begin{tabular}{ccccc}
\hline \multirow{2}{*}{ Occupation/activity } & \multicolumn{4}{c}{ Average weekly income per person (USD) } \\
\cline { 2 - 5 } & Buswahili & Kirumi & Kongoto & Marasibora \\
\hline Charcoal burning & 85 & 0 & 223 & 18 \\
Farming & 499 & 357 & 516 & 495 \\
Fishing & 81 & 38 & 148 & 28 \\
Fish mongering & 32 & 71 & 18 & 16 \\
Herding & 0 & 0 & 345 & 0 \\
Mat making & 32 & 17 & 41 & 53 \\
Total & 729 & 483 & 1291 & 610 \\
\hline
\end{tabular}

$1 \mathrm{USD}=2121.28 \mathrm{TZS} ; 31 / 12 / 2016$.

the role the two wetlands play in meeting the economic needs of the respondents who mostly live below the poverty line and utilise the two wetlands for economic sustenance. Income across the villages was spread differently. There were significant differences in incomes for charcoal $(p<0.05)$ across the four villages, while farming, fishing, mat making, herding and fish mongering had no significant differences $(p>0.05)$.

Data on income was used to identify how much money the respondents earned from the direct sales of the wetlands' goods. The data collected provided a clear indication on which wetlands goods were traded in the market or ended up in the market in one way or the other. The income of the respondents represented weekly earnings per person. These findings reflected the national trends in occupations, with farmers having the highest income. The findings of the 2012 Tanzania National Census indicated that $62.1 \%$ of the population engaged in farming and was the main occupation. Livestock keeping (herding) and fishing were practised by $2.4 \%$ and $1.0 \%$ of the population, respectively, while other elementary occupations 
constituted 6.3\% (The United Republic of Tanzania, 2012).

\subsection{Time Spent by Respondents in Harnessing Wetland Resources}

The average time spent by the respondents in carrying out their economic activities in the two wetlands is shown in Table 3. Time was used as an indicator of the dependency of the locals on the wetlands, the rationale being that a respondent spending an average of 5 hours per day on the wetland carrying out strenuous work, would not be sufficiently productive carrying out any other economic activity.

In Buswahili village, charcoal burners interviewed spent the highest amount of time (average of 8 hours/day) and the least were mat-makers at 4 hours/day on average. The charcoal burners, undeterred by lack of enforcement officials, were free to spend many hours in the wetlands. There were significant differences in the time spent in the village $(p<0.05)$ as a consequence of the charcoal burners spending more time in the wetlands as compared to other users. In Kirumi village, mat-making, which is labour intensive, took the highest time (6 hours/day on average) and fish mongering, which is less practised in the village, took the least amount of time (5 hours/day on average). There was no significant difference in the time spent across the village $(p>0.05)$, and all the wetlands users spent on average similar hours in the wetlands. Kongoto village had herdsmen spending the highest time with an average of 8 hours/day, due to vast areas of herding. The least time was spent by the mat-makers with an average of 4 hours/day. There was significant difference in the time spent among the respondents $(p<0.05)$ because they also spent similar hours in the wetlands. Marasibora village had the highest time spent by fishmongers at an average of 6 hours/day and charcoal burning, which is less practised in the village had the least time at an average of 3 hours/day. There was no significant difference in the time spent on the wetlands across this village $(p>0.05)$, and this also attributed to similar working hours in the wetlands. Having spent an average of 5 hours minimum in the wetlands, the respondents were found to not engage much in other economic activities, and any other economic activity was rather a supplementary in nature. Overall, based on the amount of time the respondents spent

Table 3. Average time spent in wetlands across the four villages.

\begin{tabular}{ccccc}
\hline \multirow{2}{*}{ Occupation/activity } & \multicolumn{5}{c}{ Average time spent per person (hours/day) } \\
\cline { 2 - 5 } & Buswahili & Kirumi & Kongoto & Marasibora \\
\hline Charcoal burning & 8 & 5 & 7 & 3 \\
Farming & 5 & 5 & 6 & 5 \\
Fishing & 6 & 5 & 5 & 5 \\
Fish mongering & 5 & 6 & 5 & 6 \\
Herding & 11 & 0 & 8 & 0 \\
Mat making & 4 & 0 & 4 & 5 \\
\hline
\end{tabular}


on the wetlands, they were classified as being very dependent economically on the two wetlands.

\subsection{Level of Knowledge on Wetland Ecosystem Services amongst the Respondents}

It is expected that some knowledge on wetland ecosystem services or general environmental education helps communities in wetland conservation. In this study, only $6 \%$ of those interviewed regarded themselves as having some considerable knowledge on wetland ecosystem services, while the rest (94\%) thought that they lacked knowledge. Hence the minimal knowledge on wetland ecosystem services exhibited by the respondents is likely to be a catalyst for activities that negatively affect the wetlands.

\subsection{Wetland Management and Conflicts}

Using a semi-structured interview, views were sought from officials of the water users' association and a local conservation agency on the wetland management and conflicts. It emerged that village government councils are charged with the management and utilisation of wetlands in their jurisdictions. More often, these officials allotted sections of the wetlands to various villagers to undertake various economic activities without due regard to conservation. As explained earlier, the majority of the residents living around the wetlands rely on them for economic sustenance.

Other issues that were raised were conflicts and illegal activities within the wetlands. Clashes between herders and farmers who engaged in cropping were common. The latter often accused the former of letting loose their livestock on their crops. There were also illegal activities reported, for instance unsustainable fishing and destruction of biodiversity. These illegal activities were fuelled by market forces and poor enforcement by village government officials. Other activities that threatened the sustainability of the two wetlands include unsustainable harvesting of papyrus, use of synthetic fertilisers in farming and the use of biomass for charcoal production.

The locals over-rely on the papyrus for mat-making. Papyrus mats are cheap and cost-effective to make, and hence preferred by the locals. However, the money raised from sale of mats is low, and this drives the locals to use more papyrus which leads to unsustainable use. In a bid to improve their yields due to deteriorating soils, the farmers apply synthetic fertilisers which the conservation officials reported to be impacting the Mara River and Lake Victoria.

\subsection{Negative Impacts on Wetlands and Proposed Mitigation Strategies}

Negative impacts

Mara Bay and Masirori wetlands are of great importance economically to the residents of the Mara region based on the dependency of the local communities on the two wetlands for economic sustenance. However, as shown by Davidson 
(2014), the anthropogenic activities that are carried out in wetlands in Africa due to reliance on these resources, oftentimes have negative ramifications on them. Studies undertaken on the wetlands within the Great Lakes region show that conversion of wetlands to farm lands, fuel wood and charcoal harnessing, river flow modification, poverty and weak translation of management policies are some of the major issues which afflict most wetlands (Brooks \& Thompson, 2001).

From the study of the two wetlands, issues arising from income generation activities for the markets were highlighted. These issues contributed to the destruction of the wetlands while the locals went about harnessing resources for the local markets. The results of this study support the findings of Mombo et al. (2011) which showed that the Mara wetlands are a source of economic sustenance to the locals who rely on them for income, food and water. This was indicated by the time the villagers spend on the wetlands harnessing the goods.

Like many African wetlands facing pressures from farming (Van Dam et al., 2014; Barbier, 1993), the findings from the field study and reports from the conservation officials in the area showed that parts of Mara Bay and Masirori wetlands were used as farm lands (for instance maize farm as shown in Figure 3). Conversion of the two wetlands into farmlands is rampant because agriculture is the major economic backbone of the region and a source of income to many communities in Tanzania (Mombo et al., 2011). In convergence with the findings of Ostrovskaya et al. (2013), poor management and enforcement of policies is the major cause of ecological destruction in the two wetlands. In this study, farming was found to be spread across the four villages, with Kongoto village generating the highest income at a total of US $\$ 516$. The residents are allotted farmlands inside the wetlands by government officials who have no training in environmental matters.

As shown by similar studies undertaken by Musamba et al. (2011), the current study identified livestock keeping as a major economic activity in the Mara

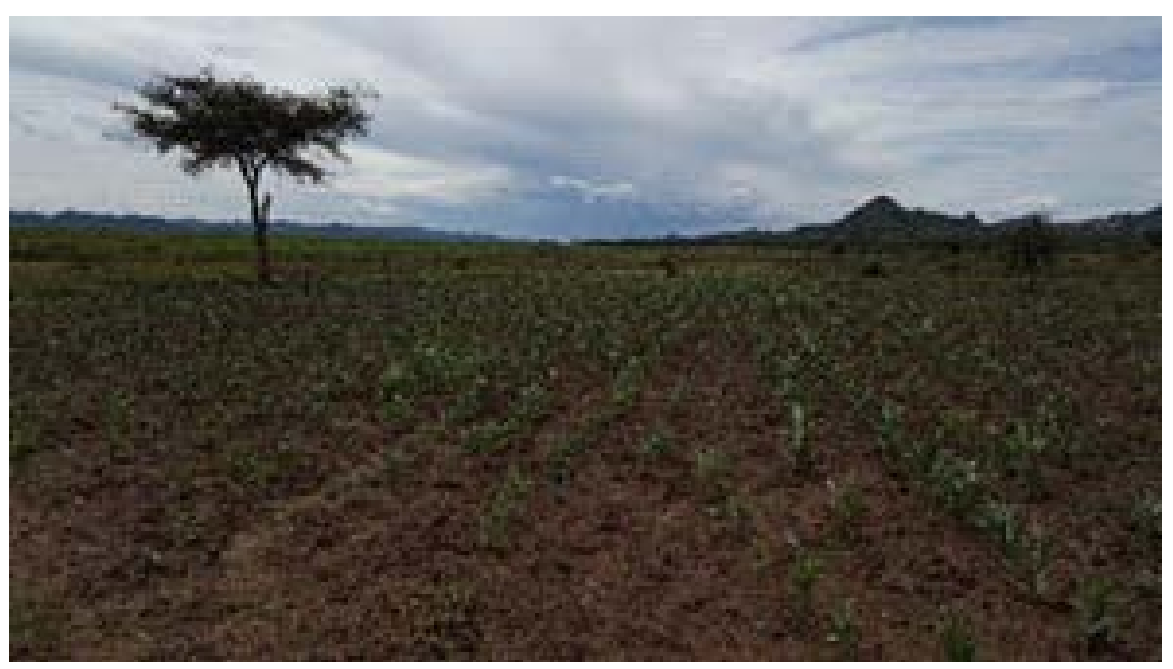

Figure 3. A maize plantation in the wetland. 
region. The residents in the region keep livestock mostly as a financial back-up during difficult financial times and sell them to generate quick cash during financial emergencies. Herding was highest in Kongoto village where the total income was US \$ 345 . There was no significant difference in the income generated from herding. Use of wetlands as grazing lands is an issue in most African wetlands (Musamba et al., 2011) because of the damage caused by the hooves on the top soil. The study equally verified this in the two wetlands, and also by concerns raised by the conservation officials in the area. The study concurred with Dessu and Melesse (2013) and Mango et al. (2011) that one of the main reasons why the communities turn to the wetlands for grazing lands is because of increased population in the region. With the increase in the population and reduced grazing sites, the locals therefore turn to the wetlands for pasture and watering of the livestock, consequently increasing the pressure on the two wetlands.

Charcoal burning is a major threat to African wetlands, because of the destruction of vegetation which are vital for maintaining the wetlands' regulatory functions in sequestering carbon (Beuel et al., 2016). The activity of charcoal generation in the two wetlands was driven by the need for cheaper fuel for the local communities who could not afford or access gas or electricity. In Tanzania, the main source of energy for cooking in terms of percentage are firewood and charcoal, at $68.5 \%$ and $25.7 \%$, respectively. Charcoal burning was very attractive to the locals as can be seen in Figure 4.

Papyrus is a major source of income for many locals in African wetlands (Van Dam et al., 2014). It is quickly processed into mats which are popular in the local markets due to their low prices and practicality in use in almost any household's setting (Figure 5). In this study, it emerged from the different sources of information that papyrus harvesting from the two wetlands was happening rapidly and in unsustainable manner due to low mat prices in the markets. This leads to the loss of papyrus and habitats for various herbivorous species such as sitatunga (Tragelaphus spekii) and hippo (Hippopotamus amphibious). Among the respondents interviewed, makers were the majority at $31 \%$, yet they were the group

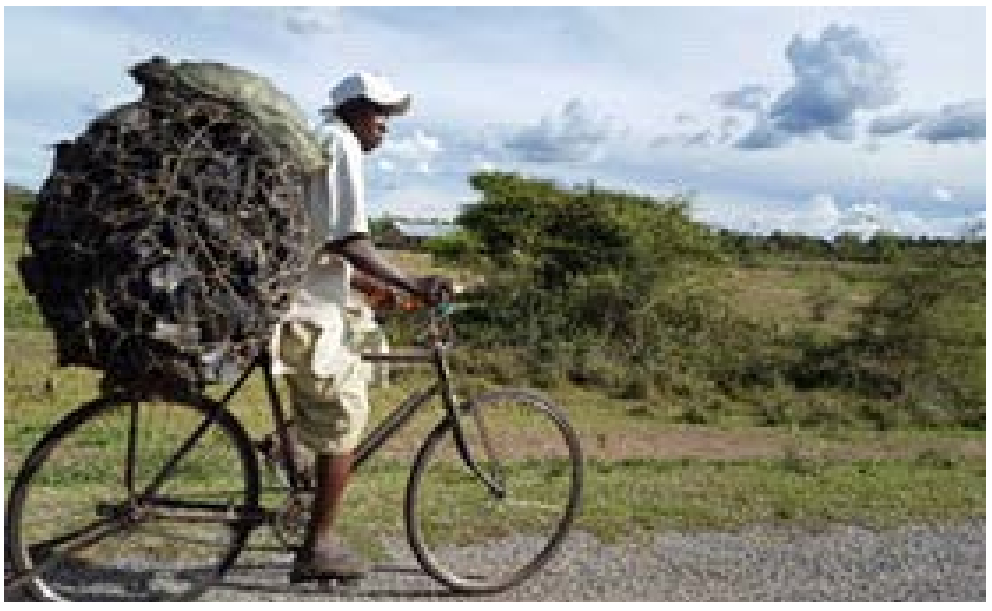

Figure 4. Charcoal being transported to the market using a bicycle. 
with the lowest income generated at only a total of US $\$ 53$ per group/week in Marasibora village.

Fishing was also found to be popular amongst the respondents interviewed, with $25 \%$ of them being fishermen. Fishing is a major source of income and food for many African communities living around lakes and wetlands (Koohafkan et al., 1998). However, the challenge with fishing in the African context is ensuring that it is done in a sustainable manner. In many areas of Africa, there is an issue with using smaller-meshed nets in order to capture more fish. However, this leads to the capture of immature fish and in some instances unhatched eggs, and this is usually driven by the desire of fishermen and fish mongers for more sales in open markets (Figure 6). Fishing income had no significant difference across the four villages the fishermen enjoyed similar prices across the four villages in the two study areas.

An economic activity which was only identified during the field work and was never anticipated was brick-making. In this activity, the top soil is used to bake clays into bricks and this is what causes a challenge in the management of wetlands in the region. The soils in the wetlands soils are known to sequester carbon

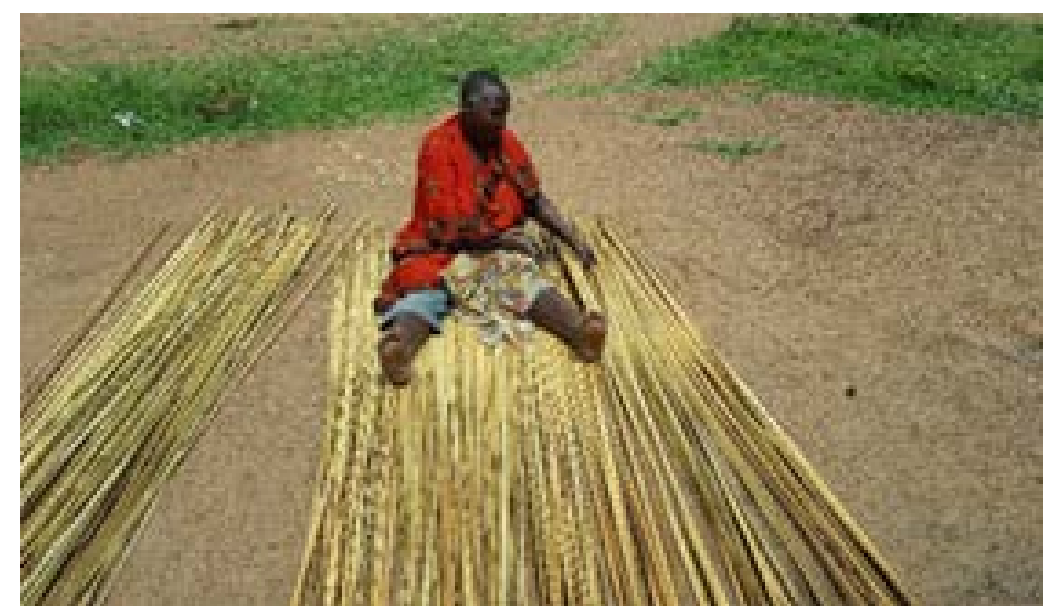

Figure 5. A resident using papyrus to make mats for sale.

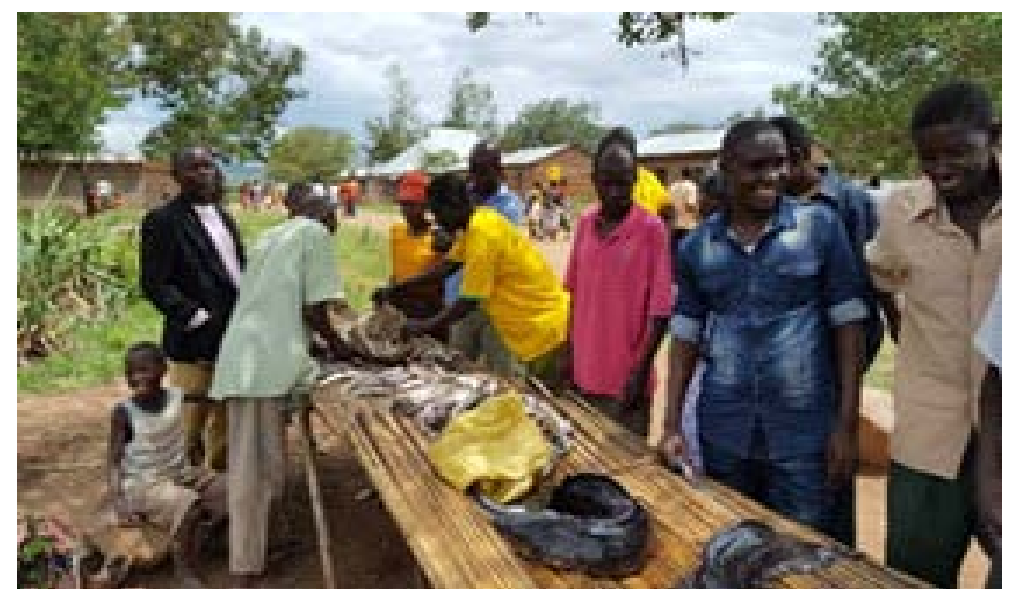

Figure 6. A fish trader serves customers at Kirumi market. 
(Chmura et al., 2003) which is released during the baking process, hence the process not only releases carbon back into the atmosphere, but also destroys the chemical and biological composition of the soils in the wetlands. This economic activity was seen scattered around the study area, and the conservation officials indicated that a stack of 20 bricks would retail for US \$ 1 . While the cost of mud bricks are much lower than the conventional bricks chiselled out of stone, the bricks are often sold in the range of hundreds in order to make more money by the local residents.

Consequences on the provisioning services

The factors discussed above have a number of impacts on the ecosystem services of the two wetlands. Firstly, they lead to the reduction in provisioning capabilities of the two wetlands. Davidson (2014) argues that uncontrolled harvesting results in slow reduction in the capacity wetlands to provide ecosystem services. In this study, economic activities such as fishing and mat-making using papyrus (papyrus provide shelter for young fish) were found to be undertaken in an unsustainable manner. This will eventually reduce the provisioning services of the two wetlands, implying that in the near future, the two wetlands will not be able to fully provide for these resources without facing further pressure.

The vegetation in wetlands to act as carbon sinks (Beuel et al., 2016), and enables the wetlands to help in regulating services (Beuel et al., 2016). The destruction of trees and other vegetation was found to be happening as a result of charcoal burning. The economic activity is therefore reducing the ability of the two wetlands to regulate climate as needed. Another economic activity which impacted on the wetlands' regulatory ability is the reduction in storm and flood control due to loss of papyrus (MEA-Millennium Ecosystem Assessment, 2005).

Previous studies have shown that wetlands help in the accumulation of organic matter and sediment retention during soil formation (Davidson, 2014). Soil formation and nutrient cycling are the essential supporting services wetlands provide (MEA-Millennium Ecosystem Assessment, 2005). Wetlands have also been found to store more carbon in the soils than even rainforests. Soils found in wetlands help with the regulatory and supporting services, and this shows how cross-cutting the wetland ecosystem services can be. The activity of using the wetlands as grazing lands also has negative effects on the top soil in the two wetlands. The hooves of livestock loosen the top soil (Ajwang et al., 2016), making it vulnerable to erosion during rain events leading to not only loss of nutrients, but also turbidity in the wetland waters as well as Lake Victoria.

The two wetlands carry a lot of biodiversity and are endangered bird hotspot sanctuaries (Kassenga, 1997; Sritharan \& Burgess, 2012). These wetlands are aesthetic and educational, and provide cultural services in the region. The destruction of biodiversity in these wetlands during various income-generation activities leads to the slow decline of the cultural support offered by the two wetlands. Perhaps more troubling is the possibility that some of the biodiversity 
could be endangered or become extinct in the near future.

Conversion of wetlands into farmlands has caused massive reduction in wetlands (Ajwang et al., 2016), and thus a reduction in the ecosystem services provided by these wetlands. In the current study conversion of sections of wetlands to farmlands was found to be on the increase in the two wetlands. This was found to be driven by the fact that the region relies economically on agriculture and also due to uninformed allotment done by the government officials. Therefore, conversion into farmlands in this study is viewed as the biggest threat because farmers use synthetic fertilizers which get washed in the waters and soils, affecting the biodiversity and may lead to the eventual loss of the two wetlands.

Studies done by Davidson (2014) and Ajwang et al. (2016) attribute total wetland losses to unsustainable anthropogenic forces aided by improper management. The present study also argues that, based on the information from the survey and documented impacts, the existence of the two wetlands in the long run is endangered by the presence of markets around the region, and that they soon cease to function properly unless quick interventions are put in place to help mitigate these impacts.

Proposed mitigation strategies

Therefore, the study proposed different strategies to help mitigate the destruction taking place in the two wetlands, these strategies were adapted from the following sources: Turner (1991), and Davis and Froend (1999), and from the ideas of the conservation officials and water users' association leaders. These included, improved environmental education, attachment of wetlands ecologists or conservation professionals to the village governments, valuation of the Mara wetlands resources and commissioning of a price and resource regulatory board in the Mara wetlands basin, creation of wetlands monitoring program and a fining regime system.

\section{Conclusion}

The main objective of this study was to help highlight the negative impacts of economic activities on wetlands in East Africa with a specific focus on Mara Bay and Masirori wetlands. This was achieved by highlighting the findings obtained from the surveys. Most of the findings from this study were found to be similar to those obtained from other studies carried out in the Lake Victoria basin. The lack of understanding of ecosystem services by the respondents from the four villages was thought to be the cause of the propagation of harmful activities on the two wetlands by the locals. Therefore, urgent intervention is needed to help reverse the damage that is already happening, and to find alternative means of livelihoods for the locals. This is anticipated to help create a scenario in which the management process will be beneficial to both the locals and the threatened wetlands.

The findings however highlight the plight of most wetlands in East Africa and show how they are on the path to further destruction unless appropriate inter- 
ventions are put into place. The findings also help highlight the low economic conditions of most locals living around these wetlands, and the effect this can have on conservation efforts. Future research in the region could expand the study area and engage more respondents to get additional responses which may be used to improve the research. Studies should also be done to model an economic scenario where the locals are completely kept away from the wetlands and a break-even scenario benefiting the locals also modelled in this instance to achieve conservation as well as improve the local's livelihood.

\section{Acknowledgements}

This study would like to thank Birdlife Tanzania, for the support accorded during the field work, and IHE Delft and CQU Australia supervisors for their guidance and support in the development of this paper.

\section{Conflicts of Interest}

The authors declare no conflicts of interest regarding the publication of this paper.

\section{References}

Ajwang' Ondiek, R., Kitaka, N., \& Omondi Oduor, S. (2016). Assessment of Provisioning and Cultural Ecosystem Services in Natural Wetlands and Rice Fields in Kano Floodplain, Kenya. Ecosystem Services, 21, Part A, 166-173. https://doi.org/10.1016/j.ecoser.2016.08.008

Barbier, E. B. (1993). Sustainable Use of Wetlands Valuing Tropical Wetland Benefits: Economic Methodologies and Applications. The Geographical Journal, 159, 22-32. https://doi.org/10.2307/3451486

Beuel, S., Alvarez, M., Amler, E., Behn, K., Kotze, D., Kreye, C., \& Becker, M. (2016). A Rapid Assessment of Anthropogenic Disturbances in East African Wetlands. Ecological Indicators, 67, 684-692. https://doi.org/10.1016/j.ecolind.2016.03.034

Brooks, T., \& Thompson, H. S. (2001). Current Bird Conservation Issues in Africa. The Auk, 118, 575-582. https://doi.org/10.1642/0004-8038(2001)118[0575:CBCIIA]2.0.CO;2

Chmura, G. L., Anisfeld, S. C., Cahoon, D. R., \& Lynch, J. C. (2003). Global Carbon Sequestration in Tidal, Saline Wetland Soils. Global Biogeochemical Cycles, 17, 1111. https://doi.org/10.1029/2002GB001917

Costanza, R., D’Arge, R., De Groot, R., Farber, S., Grasso, M., Hannon, B., Limburg, K., Naeem, S., O’neill, R. V., Paruelo, J., Raskin, R. G., Sutton, P., \& Van den Belt, M. (1997). The Value of the World's Ecosystem Services and Natural Capital. Nature, 387, 253-260. https://doi.org/10.1038/387253a0

Crisman, T. (2001). Wetlands of East Africa: Biodiversity, Exploitation, and Policy Perspectives.

Davidson, C. N. (2014). How Much Wetland Has the World Lost? Long Term and Recent Trends in Global Wetland Area. Marine and Freshwater Research, 65, 934-941. https://doi.org/10.1071/MF14173

Davis, J. A., \& Froend, R. (1999). Loss and Degradation of Wetlands in Southwestern Australia: Underlying Causes, Consequences and Solutions. Wetlands Ecology and 
Management, 7, 13-23. https://doi.org/10.1023/A:1008400404021

Dessu, S. B., \& Melesse, A. M. (2013). Impact and Uncertainties of Climate Change on the Hydrology of the Mara River Basin, Kenya/Tanzania. Hydrological Processes, 27, 2973-2986.

Devetak, I., Glažar, S. A., \& Vogrinc, J. (2010). The Role of Qualitative Research in Science Education. Eurasia Journal of Mathematics, Science \& Technology Education, 6, 77-84. https://doi.org/10.12973/ejmste/75229

Dixon, A. B., \& Wood, A. P. (2003). Wetland Cultivation and Hydrological Management in Eastern Africa: Matching Community and Hydrological Needs through Sustainable Wetland Use. Natural Resources Forum, 27, 117-129. https://doi.org/10.1111/1477-8947.00047

Durigon, D., Hickey, G. M., \& Kosoy, N. (2012). Assessing National Wetland Policies' Portrayal of Wetlands: Public Resources or Private Goods? Ocean \& Coastal Management, 58, 36-46. https://doi.org/10.1016/j.ocecoaman.2011.12.008

Hettiarachchi, M., Morrison, T. H., \& McAlpine, C. (2015). Forty-Three Years of Ramsar and Urban Wetlands. Global Environmental Change, 32, 57-66.

https://doi.org/10.1016/j.gloenvcha.2015.02.009

Hoffman, C., Melesse, A., \& McClain, M. (2011). Geospatial Mapping and Analysis of Water Availability, Demand, and Use within the Mara River Basin. Miami, FL: Florida International University.

Kadykalo, A. N., \& Findlay, C. S. (2016). The Flow Regulation Services of Wetlands. Ecosystem Services, 20, 91-103. https://doi.org/10.1016/j.ecoser.2016.06.005

Kassenga, G. R. (1997). A Descriptive Assessment of the Wetlands of the Lake Victoria Basin in Tanzania. Resources, Conservation and Recycling, 20, 127-141. https://doi.org/10.1016/S0921-3449(97)00014-1

Kirk, R. E. (1995). Experimental Design: Procedures for the Behavioral Sciences (3rd ed.). Pacific Grove, CA: Brooks/Cole.

Koohafkan, P., Nachtergaele, F., \& Antoine, J. (1998). Use of Agro-Ecological Zones and Resource Management Domains for Sustainable Management of African Wetlands. In Wetland Characterization and Classification for Sustainable Agricultural Development. Rome: FAO/SAFR.

Majamba, H. I. (2004). Implementing the Ramsar Convention in Tanzania: Salient Features of Legislation and Policies for the Management and Conservation of Wetlands.

Mango, L. M., Melesse, A. M., McClain, M. E., Gann, D., \& Setegn, S. (2011). Land Use and Climate Change Impacts on the Hydrology of the Upper Mara River Basin, Kenya: Results of a Modeling Study to Support Better Resource Management. Hydrology and Earth System Sciences, 15, 2245. https://doi.org/10.5194/hess-15-2245-2011

Millennium Ecosystem Assessment (2005). Ecosystems and Human Well-Being: Wetlands and Water Synthesis. Washington DC: World Resources Institute.

Mombo, F. M., Speelman, S., Van Huylenbroeck, G., Hella, J., Pantaleo, M., \& Moe, S. (2011). Ratification of the Ramsar Convention and Sustainable Wetlands Management: Situation Analysis of the Kilombero Valley Wetlands in Tanzania. Journal of Agricultural Extension and Rural Development, 3, 153-164.

Mombo, F., Speelman, S., Hella, J., \& Van Huylenbroeck, G. (2013). How Characteristics of Wetlands Resource Users and Associated Institutions Influence the Sustainable Management of Wetlands in Tanzania. Land Use Policy, 35, 8-15. https://doi.org/10.1016/j.landusepol.2013.04.010

Musamba, E. B., Ngaga, Y. M., Boon, E. K., \& Giliba, R. A. (2011). Impact of So- 
cio-Economic Activities around Lake Victoria: Land Use and Land Use Changes in Musoma Municipality, Tanzania. Journal of Human Ecology, 35, 143-154.

https://doi.org/10.1080/09709274.2011.11906400

Ostrovskaya, E., Douven, W., Schwartz, K., Pataki, B., Mukuyu, P., \& Kaggwa, R. C. (2013). Capacity for Sustainable Management of Wetlands: Lessons from the WETwin Project. Environmental Science \& Policy, 34, 128-137. https://doi.org/10.1016/j.envsci.2012.08.006

Patton, D., Bergstrom, J. C., Moore, R., \& Covich, A. P. (2015). Economic Value of Carbon Storage in US National Wildlife Refuge Wetland Ecosystems. Ecosystem Services, 16, 94-104. https://doi.org/10.1016/j.ecoser.2015.10.017

Peh, K. S. H., Balmford, A., Bradbury, R. B., Brown, C., Butchart, S. H. M., Hughes, F. M. R., Birch, J. C. et al. (2013). TESSA: A Toolkit for Rapid Assessment of Ecosystem Services at Sites of Biodiversity Conservation Importance. Ecosystem Services, 5, 51-57. https://doi.org/10.1016/j.ecoser.2013.06.003

Ramsar Convention Secretariat (2013). The Ramsar Convention Manual: A Guide to the Convention on Wetlands (Ramsar, Iran, 1971) (6th ed.). Gland: Ramsar Convention Secretariat.

Sakane, N., Alvarez, M., Becker, M., Böhme, B., Handa, C., Kamiri, H. W., Mogha, N. G. et al. (2011). Classification, Characterisation, and Use of Small Wetlands in East Africa. Wetlands, 31, 1103-1116. https://doi.org/10.1007/s13157-011-0221-4

Schuijt, K. (2002). Land and Water Use of Wetlands in Africa: Economic Values of African Wetlands. IIASA Interim Report, IR-02-063, Laxenburg: IIASA. http://pure.iiasa.ac.at/6723/

Scoones, I. (1991). Wetlands in Drylands: Key Resources for Agricultural and Pastoral Production in Africa. Ambio, 20,366-371.

Sritharan, S., \& Burgess, N. D. (2012). Protected Area Gap Analysis of Important Bird Areas in Tanzania. African Journal of Ecology, 50, 66-76. https://doi.org/10.1111/j.1365-2028.2011.01295.x

Taylor, A. R. D., Howard, G. W., \& Begg, G. W. (1995). Developing Wetland Inventories in Southern Africa: A Review. Classification and Inventory of the World's Wetlands, 118, 57-79. https://doi.org/10.1007/978-94-011-0427-2_7

The United Republic of Tanzania (2012). Basic Demographic and Socio Economic Profile, 2012 Population and Housing Census.

Turner, K. (1991). Economics and Wetlands Management. Ambio, 20, 59-63. http://www.jstor.org/stable/4313777

Van Dam, A., Kipkemboi, J., Mazvimavi, D., \& Irvine, K. (2014). A Synthesis of Past, Current and Future Research for Protection and Management of Papyrus (Cyperus papyrus L.) Wetlands in Africa. Wetlands Ecology and Management, 22, 99-114. https://doi.org/10.1007/s11273-013-9335-1

Wu, S., Carvalho, P. N., Müller, J. A., Manoj, V. R., \& Dong, R. (2016). Sanitation in Constructed Wetlands: A Review on the Removal of Human Pathogens and Fecal Indicators. Science of the Total Environment, 541, 8-22. https://doi.org/10.1016/j.scitotenv.2015.09.047 